\title{
GOVERNABILITY OR GOVERNANCE IN WATER RESOURCE MANAGEMENT. THE COLOMBIAN CASE *
}

\section{Gobernabilidad o gobernanza en la gestión del recurso hídrico. el caso colombiano}

Manuel-Alberto Restrepo-Medina**

María-Angélica Nieto-Rodríguez ${ }^{* * *}$

Recepción: 22/11/2019. Aceptación: 14/12/2019

DOI: http://dx.doi.org/10.21017/Rev.Repub.2020.v28.a81

\begin{abstract}
The aim of this article is to establish if water resource management related to water supply, demand, quality, and risks in the Colombian case has transitioned from governability to governance. The concept of water governability refers to institutional competence in the design and effective implementation of socially acceptable public policies. Water governance pertains to transparency, accountability, and responsiveness in the definition and implementation of public policies for water management involving democratic mechanisms and institutions that prioritize social interest articulation. This distinction is important because the governability model is designed to simplify all water management processes related to the adoption and implementation of public policies; however, this approach tends to ignore the fact that water problems are wide reaching and complex as they involve all aspects of society, including culture, the economy, and law. The governance model, by contrast, considers
\end{abstract}

* Este artículo es producto del proyecto de investigación Perspectivas de la implementación de la Agenda 2030 y sus Objetivos de Desarrollo Sostenible en Colombia a la luz del Acuerdo de París sobre cambio climático, cofinanciado por Colciencias y la Universidad del Rosario.

* Ph D en Derecho, Universidad Alfonso X el Sabio. Magister en Derecho Administrativo, Universidad del Rosario. Magister en Estudios Políticos, Pontificia Universidad Javeriana. Especialista en Legislación Financiera, Universidad de los Andes. Abogado, Universidad del Rosario. Profesor titular de carrera académica de la Universidad del Rosario, Bogotá, Colombia, manuel.restrepo@urosario.edu.co. https:/ / orcid.org/0000-0003-01978353

*** Especialista en Derecho Sustantivo y Contencioso Constitucional, Pontificia Universidad Javeriana. Abogada, Universidad del Rosario. Estudiante de la maestría en derecho administrativo de la Universidad del Rosario, Bogotá, Colombia, mariaan.nieto@ urosario.edu.co. https://orcid.org/0000-0003-4316-5238 
such factors. This article discusses the distinction between water governability and water governance as well as the shift from an integral water resource management model to a water governance paradigm. Next, the particular characteristics of the Colombian case are explained. Finally, the elements of governance within the Colombian system are analyzed to establish whether a transition has been achieved.

Key words: water resource management, governability, governance, sustainable development, Colombia.

\section{RESUMEN}

El objeto de este artículo es establecer si la gestión del recurso hídrico, referente al suministro, demanda, calidad y riesgos, ha transitado en el caso colombiano de la gobernabilidad a la gobernanza. El concepto de gobernabilidad del agua se refiere a las competencias institucionales para el diseño y la implementación efectiva de políticas públicas socialmente aceptables. La gobernanza del agua alude a la transparencia, rendición de cuentas y responsabilidad en la definición e implementación de las políticas públicas de gestión del agua, que involucran mecanismos democráticos e instituciones que priorizan la articulación de los intereses sociales. Esta distinción es importante porque el modelo de la gobernabilidad está diseñado para simplificar todos los procesos de gestión del agua relativos a la adopción e implementación de políticas públicas; sin embargo, esta aproximación tiende a ignorar el hecho de que los problemas del agua alcanzan un alto grado de complejidad e involucran todos los aspectos de la sociedad, incluyendo la cultura, la economía y el derecho. En contraste, el modelo de gobernanza considera todos estos factores. Este artículo comienza por presentar la distinción entre gobernabilidad y gobernanza del agua al tiempo con el paso de un modelo de gestión integral del recurso hídrico a un paradigma de la gobernanza del agua. Luego son explicadas las principales características del caso colombiano y finalmente se analiza si los elementos de la gobernanza están presentes en el caso colombiano para determinar si la transición de la gobernabilidad a la gobernanza efectivamente se ha logrado.

Palabras clave: gestión del recurso hídrico, gobernabilidad, gobernanza, desarrollo sostenible, Colombia.

\section{INTRODUCTION}

Water represents a common good for all human beings because it is required daily in minimum quantities to preserve life and health; however, it is also an 
indispensable resource for other vital social needs that enable the development and progress of the human species.

In addition, water acquires a cultural sense in that it is present in many of the manifestations that give identity to social groups, such as ceremonies, rituals, and traditions, some of which are associated with expressions of progress, whereas others tend to lead to conflict.

The international community has tended to take a systematic approach to problems related to guaranteeing water quality and supply against conditions of scarcity generated by climatological phenomena and anthropogenic elements, such as pollution and inefficient use.

In search of solutions, the United Nations arrived at a set of recommendations for states to address such problems through the adoption of programs for the integral management of water resources. The programs mainly focused on regulation and management of water supply, demand, quality, and risks, which in turn required definition of the actions to strengthen the corresponding institutions and ensure the governability of the system.

Currently, there is a general consensus that water problems require solutions beyond technology or infrastructure; rather, they require coordination of social and government actions, whose success is evident when resource management programs move from governability to governance.

The aim of this article is to establish whether Colombia, based on the formulation of the National Policy for the Integral Management of Hydric Resources[1] and its implementation in phases I and II of the National Hydric Plan, underwent a transition from governability to governance in its treatment of problems related to water supply, demand, quality, and risks.

For this purpose, first, the distinction between water governability and water governance and the international shift from an integral management model of water resource to a water governance paradigm are discussed. Next, the particular characteristics of the Colombian model are explained. Finally, the elements of governance within the Colombian system are examined to establish whether a transition from governability to governance has taken place.

1 Ministerio de Ambiente, Vivienda y Desarrollo. Política nacional para la gestión integral del recurso hídrico. Bogotá: Ministerio de Ambiente, Vivienda y Desarrollo (2010). Recovered from http://extwprlegs1.fao.org/docs/pdf/col146504.pdf 


\section{WATER GOVERNABILITY AND WATER GOVERNANCE: A NECESSARY DISTINCTION}

Water governability and water governance could be understood as similar concepts that refer to institutional models for water resource management. Nevertheless, the extant literature and the work of international organizations shows that governability and governance are separate and distinct concepts.

The concept of water governability refers to the social capabilities to mobilize efforts in a coherent way for the sustainable development of water resources. This definition includes institutional competence as it relates to the design and effective implementation of socially acceptable public policies.

Water governability supposes the capacity to generate and effectively implement accurate policies. Those capacities pass through the construction of consensus, the construction of coherent management systems (regimes that comprise institutions, law, culture, knowledge, practices), and the correct management of the system (which involves participation and social acceptance, and the development of competencies).

(...)

a central element of governability is the possibility of building (establishing and developing) institutional and harmonious arrangements according to the nature, competencies, restrictions, and expectations of the system or ambit in consideration.[2]

Water governance can be defined as a wider concept than water governability in terms of transparency, accountability, and responsiveness in the definition and implementation of public policies for water management in a multilevel scheme that involves democratic mechanisms and institutions that promote social interests.

Water governance relates to the range of political, social, economic, and administrative systems that are in place to develop and manage water resources and the delivery of water services at different levels of society (Rogers \& Hall, 2003). Or put more simply, water governance is the set of systems that control decision-making with regard to water resource development and management. Hence, water governance is much more about

2 H. Peña \& M. Solanes. La gobernabilidad del agua en las Américas, una tarea inconclusa (2002). Recovered from https://gestionsostenibledelagua.files.wordpress.com/2010/ 09/gobernabilidad-del-agua-en-las-americas-una-tarea-inconclusa.pdf 
the way in which decisions are made (i.e. how, by whom, and under what conditions decisions are made) than the decisions themselves.

Water governance covers the manner in which allocative and regulatory politics are exercised in the management of water and other natural resources and broadly embraces the formal and informal institutions by which authority is exercised.[3]

The above indicates that governability models are designed to simplify all water management processes related to the adoption and implementation of public policies. The institutional center provides a general model of water management that aims to cover all needs. Nevertheless, such simplified schemes have important limitations because they tend to address water problems as they arise, rather than devising proactive water solutions; thereby, they do not consider the complexities of water problems, which can affect lives and society, including culture, the economy, and the law.

Water governability cannot be fully understood without a referential framework; however, excessive generalization leads to the formulation of common and universal solutions that ignore important contextual elements for effective formulation of an integral public policy for water. Under this perspective, democratic participation is substantially reduced because the interests of relevant social sectors are not prioritized in water management processes, and there are no effective participation mechanisms for the public to exert control over water management issues.

Governance models tend to integrate the structural complexity of water management and focus on participation and multilevel government in public policy formulation. According to the UN, "[g]overnance refers to the exercise of political and administrative authority at all levels to manage a country's affairs. It comprises the mechanisms, processes and institutions, through which citizens and groups articulate their interests, exercise their legal rights, meet their obligations and mediate their differences".[4]

Governance thus comprises an open paradigm that differs from the governability model in its structural and hierarchical boundaries. The governance model involves a multi-focal structure that combines institutional control, public

3 C. Batchelor. Water governance literature assessment. International Institute for Environment and Development (2007). Recovered from http://pubs.iied.org/pdfs/ G02523.pdf?

4 UN System Task Team on the Post-2015 UN Development Agenda. Governance and development Thematic Think Piece UNDESA, UNDP, UNESCO. (2015). Recovered from http://www.un.org/millenniumgoals/pdf/Think\%20Pieces/7_governance.pdf 
participation, democratic mechanisms, and recognizes the importance of private interests in influencing the management and distribution of water resources.

There is a growing perception that the governance of water resources and water services (and of many other things) functions more effectively within an open social structure which enables broader participation by civil society, private enterprises and the media, all networking to support and influence government. The ideology of a command and control or a hierarchical central State system caring for its citizens has been replaced in many countries by market-led water governance models. However, the honeymoon with the laissez-faire market-led model is over as it is now regarded as being too simplistic and not representative of wider societal values. The trend now is for distributed water governance systems to supplement formal authority by an increasing reliance on informal authority, for example, through genuine public-private coordination and co-operation. This can avoid governments being caught up in the contradictory roles of being both a provider and regulator of services.[5]

As such, the OECD has recognized the importance of a multi-level model of water governance whose scope is wider than a hierarchical model and leads to development and implementation of more reasonable and effective solutions according to the different aspects of water problems.

...water governance systems (more or less formal, complex, and costly) should be designed according to the challenges they are required to address. This problem-solving approach means that "forms" of water governance should follow "functions" of water governance. Structuring, institutionalising, and/ or formalising institutions should not detract from the ultimate objective of delivering sufficient water of good quality, while maintaining or improving the ecological integrity of water bodies.[6] (OECD, 2015).

The factors that support this affirmation are complex, and range from geographical factors to political issues related to water management; these can be summarized as follows:

- Water connects across sectors, places and people, as well as geographic and temporal scales. In most cases, hydrological boundaries and administrative perimeters do not coincide.

5 C. Batchelor. Water governance literature assessment. International Institute for Environment and Development (2007). Recovered from http://pubs.iied.org/pdfs/ G02523.pdf?

6 OECD. OECD Principles on Water Governance. Paris. (2015). Recovered from http:// www.oecd.org/cfe/regional-policy/OECD-Principles-on-Water-Governance.pdf 
- Freshwater management (surface and groundwater) is both a global and local concern, and involves a plethora of public, private and non-profit stakeholders in the decision-making, policy and project cycles.

- Water is a highly capital-intensive and monopolistic sector, with important market failures where co-ordination is essential.

- Water policy is inherently complex and strongly linked to domains that are critical for development, including health, environment, agriculture, energy, spatial planning, regional development and poverty alleviation.

- To varying degrees, countries have allocated increasingly complex and resource-intensive responsibilities to sub-national governments, resulting in interdependencies across levels of government that require co-ordination to mitigate fragmentation.[7]

As a direct consequence of this multi-level complexity, governments are challenged to clearly state the differences between governability and governance and to transition from a hierarchical model, where the state formulates universal public policies and general solutions for water management problems, to a model based on the coordination between government, civil society, enterprises, and different social, cultural and economic sectors. The goal of this transition is to achieve transparent processes intended to give particular responses to specific water governance problems.

Coping with current and future challenges requires robust public policies, targeting measurable objectives in pre-determined time-schedules at the appropriate scale, relying on a clear assignment of duties across responsible authorities and subject to regular monitoring and evaluation.

Water governance can greatly contribute to the design and implementation of such policies, in a shared responsibility across levels of government, civil society, business and the broader range of stakeholders who have an important role to play alongside policy-makers to reap the economic, social and environmental benefits of good water governance.[8]

Although the reasons for the adoption of a water governance model are persuasive, the transition process has not been easy. Despite international le-

7 OECD. OECD Principles on Water Governance. Paris. (2015). Recovered from http:// www.oecd.org/cfe/regional-policy/OECD-Principles-on-Water-Governance.pdf

8 OECD. OECD Principles on Water Governance. Paris (2015). Recovered from http:// www.oecd.org/cfe/regional-policy/OECD-Principles-on-Water-Governance.pdf 
gal development of this concept, its implementation still represents one of the greater difficulties for water resource management. The following sections discuss in detail this transition process.

\section{FROM THE INTEGRAL MANAGEMENT OF HYDRIC RESOURCES TO WATER GOVERNANCE}

Water is necessary for the existence and subsistence of humanity. The international community has mainly focused on ensuring water supplies, formulating public policies for its management, and adopting the governance paradigm in carrying out these objectives.

In a study about Mexican public policy on water resources, Salcido, Gerritsen and Martínez[9] review how that topic has been addressed in the international community. They began with a discussion of the Declaration of the United Nations Conference on Human Environment (1972), which proclaimed that the human beings, whose activities caused substantial environmental damage, such as water contamination and the destruction and exhaustion of natural sources. The Declaration expressed the need to create environmental policies to preserve natural ecosystems while allowing economic growth.

In 1977, the United Nations Conference on Water was held to discuss issues related to water use efficiency, potable water shortages, and waste disposal. The conference gave way to the Mar del Plata Action Plan (1977), which recognized water as a limited resource that should be protected with legislation that allows efficient and equitable use of this resource.

In 1980, the International Drinking Water Supply and Sanitation Decade (IDWSSD) was proclaimed to shed light on the fact that a large part of the world population has insufficient access to water or water sanitation services. The IDWSSD made a commitment to improve those services for the year of 1990 and invited participants to develop policies to fulfill this aim.

By the end of the 1990s, the Regional Conference on Water Supply and Sanitation took place in Puerto Rico, where each country reflected on its own experience during the IDWSSD and confirmed that problems related to water stem from multiple causes. Solutions must, therefore, draw from integrated perspectives and not a technological approach exclusively.

9 S. Salcido, P. R. Gerritsen \& L. M. Martínez. Gobernanza del agua a nivel local: estudio de caso en el municipio de Zapotitlán de Vadillo, Jalisco. El Cotidiano, (162), 83-89 (2010). 
At the Global Consultation on Water Supply and Sanitation (1990), a call to all nations was made to guarantee these two basic human needs for their respective populations. The results of this Consultation were embodied in the New Delhi Declaration, which outlined the goal of "sharing water in a more equitable way." The Declaration recommended integrated management of hydric resources, and solid and liquid residues.

The Dublin Declaration on Water and Sustainable Development (1992) set out in one of its principles that decision-making should involve policy makers and users, as well as public consultations for both planning and implementation of water-related projects. With a view to achieving sustainable development, a global strategy called Program 21 was agreed upon at the United Nations Conference on Environment and Development in 1992, which reiterated the importance of water management at the local level.

In the mid-1990s, the World Water Forum began. The Forum takes place every three years, starting in 1997 in Marrakech. Participants from political and academic institutions and corporations identify and discuss problems related to water management deriving from climate change, world population growth, food safety, and the relationships among water, energy, and shortage of hydric resources.

The recommendations stemming from the World Water Forum and the willingness state administrations to implement water management strategies in their territories shows that wide acceptance that water is a problem whose solution lies in the sociopolitical process. This would entail coordination of social and governmental action in addition to technological and infrastructure development.

The problem is thus generally no longer considered a matter of shortage, lack of technology, or insufficient distribution, but as a mainly social question requiring a worldwide solution. To meet societal needs, and in order for states to act effectively, the concept of governance has been extended, particularly the concepts of water and environmental governance.

The spread of the concept of governance is closely related to recent changes in the world stage. As a result of economic and financial globalization, technological advances, and other phenomena caused by globalization, the state has lost its predominance in issues related to development and public regulation; therefore, there has been a shift toward strategies to increase interactions among a growing multiplicity of public and private actors at the national and international level. 
To analyze and understand the decision making processes of states, the concept of governability has been abandoned because it is limited to the politicalinstitutional ambit. The concept of governance, however, incorporates political and social processes and includes the participation of actors other of states. Thus, the concept of governance better addresses the complexities of relations between the state, the market, and civil society.

According to Iza[10], governance is the exercise of economic, political, and administrative authority in the management of a country's affairs at all levels. It includes the mechanisms, processes, and institutions through which citizens express their interests, exercise their rights, satisfy their obligations, and solve their differences. To that extent, governance can be described as the means through which society defines its goals and priorities and advances global, regional, national, or local cooperation.

In relation to water resources, a transition from the idea of water management to that of water governance has occurred, allowing reference to deeper linking processes between society and the state through public policies for resource management. The concept of water governance extends beyond government and management, reaching for a more inclusive concept of societal linkages and networks to monitor water resources and to implement water services at different levels[11].

Water governance refers to the way in which governmental action is linked with the actions of different independent social or government actors to produce public action, which is expressed in the form of public policies. This assumes that there is a significant level of decentralization of water governance with the participation of various social actors in the design, implementation and monitoring of water policy. The central assumption is that democratic forms of government allow the development of the public action without the absolute predominance of a relevant actor...it seems that the asymmetries of power and the use of public spaces would be regulated through the same democratic system.[12]

10 A. O. Iza \& M. B. Rovere, M. B. (Eds.) Gobernanza del agua en América del Sur: Dimensión ambiental. Cambridge: UICN (2006). Recovered from https:/ / www.iucn.org/ sites/ dev/files/import/downloads/gobernanza.pdf

11 P. Rogers \& A. W. Hall, A. W. Effective Water Governance (Vol. 7). Stockholm: Global water partnership. (2003). Recovered from https://www.gwp.org/globalassets/global/toolbox/ publications/background-papers/07-effective-water-governance-2003english.pdf

12 D. Soares, S. Vargas \& M. R. Nuño. La gestión de los recursos hídricos: realidades y perspectivas. Guadalajara: Instituto Mexicano de Tecnología del Agua, Universidad de Guadalajara (2008). 
The present paper explores public policy on water governance in Colombia and distinguishes between water governance and water management, especially as they relate to integrated or integral water resources management (IWRM).

IWRM is defined as a

\begin{abstract}
process that promotes coordinated management and development of water, land, and related resources in order to maximize the resultant economic and social welfare in an equitable manner without compromising the sustainability of vital ecosystems, while water governance is understood as the range of political, social, economic and administrative systems which are established to develop and manage water resources and water supply at different levels of society.[13]
\end{abstract}

Through management of the supply, distribution, use, and disposal of water, the costs incurred and the profits generated can be controlled; however, this does not guarantee the effectiveness of the institutional arrangements in encouraging participation and social equity, which are elements inherently linked to governance.

This is because governance is a political process involving the exercise of political power by political actors who seek to define the ends and values that must inform social development. It also comprises the identification of means to pursue those ends and values, and the adoption of suitable arrangements for the exercise of authority and power in the process.

...the determination of the ends and values in relation to water management, and the selection of the means to pursue those ends and values, does not happen in a social vacuum. Rather than being the result of a balanced partnership, the process of water governance resembles a highly asymmetric and evolving structure where the actors tend to have dissimilar proportions of political power and knowledge. In practice, water policies that have often a significant political content are designed and implemented with disregard for the values, opinions, and preferences of the citizens and in the absence of democratic governance arrangements.

13 Global Water Partnership. Principios de gestión integrada de los recursos hídricos. Bases para el desarrollo de los planes nacionales. (2008). Recovered from https:// agua.org.mx/wp-content/uploads/2011/10/principios_gestion_integrada_recursos_ hidricos.pdf 
In practice, water governance consists in the interaction between governments, large businesses, political parties, civil and other organizations representing sectoral interests (e.g. workers' unions, religious organizations, peasant movements, etc.), international agencies (e.g. international financial institutions and other agents of the process of "global governance"), NGOs, and other relevant powerholders. These actors are involved in continuing debates and in social and political confrontations around how water and essential water services should be governed, by whom, and for whom. These confrontations are at the heart of the process of democratic water governance, which is characterized not only by dialogue and negotiation but also, unfortunately, by growing uncertainty and protracted social and political conflicts.[14]

\section{THE COLOMBIAN WATER MANAGEMENT MODEL}

In Colombia, the Ombudsman Office's document «Advance to the Human Right to Water» indicates that waters are understood as public domain goods of National property, which means they are legally and constitutionally public domain property, even though for some, they are also an essential element of the territorial component of the State.[15]

In this sense, the nation designates water as an eminent domain. That does not mean that it is to be considered usufruct as if it were a fiscal good, or an absolute property right, but on the contrary, it is a formal right that is excluded from trade, granting water the status of inalienability and imprescriptibility.

To this extent, water, like all public domain goods, is «res extra commercium and its affectation can promote and ensure public use»[16] which means that the state can impose the obligation of care, preservation, conservation, and administration for the use, utilization and exploitation of the resource in a proportional, equitable, equal, and fair way.

Therefore, the concept of public ownership, in the sense of state ownership, should not be understood as a domain with inherent faculties of use, enjoyment,

14 J. E. Castro. Water governance in the twentieth-first century. Ambiente \& Sociedade, 10 (2), 97-118. (2007). Recovered from https://doi.org/10.1590/S1414-753X2007000200007

15 This affirmation is supported on the articles 674, 677 and 678 of Colombian Civil Code and articles 80 and 85 of the National Code of Renewable Natural Resources and Environmental Protection.

16 Defensoría del Pueblo. Avance del derecho humano al agua en la Constitución, la ley, la Jurisprudencia y los instrumentos internacionales 2005-2011. Bogotá, D.C. (2012). 
and abuse of a good, but as a power of the state to regulate the use of the water resource of public domain. The right of use can be acquired by the ministry of law or by permission, concession, or association.

The Code of Renewable Natural Resources thus states that all citizens have the right to use public domain waters to satisfy their basic needs, those of their families, and those of their animals, provided that this does not harm third parties. Moreover, the use must be made without derivations, employing machines or apparati, stopping or diverting the course of the waters, or deteriorating the channel or river banks, or altering or contaminating the waters in a way that renders them unusable by third parties.

For the Ministry of Environment and Sustainable Development of the Colombian Government, waters are public domain. As such, it would be possible with regulation to guarantee the sustainability of water resources through the conservation of strategic ecosystems and hydrological processes that ensure the supply of the resource, the optimization of the country's water demand, the improvement of water quality, and the reduction of contamination. These objectives require public and private activity at all sectors and segments of the population.

Given the above, it is not necessary to resort to ownership of private water investment to guarantee the sustainability of access to the resource, and instead requires integral management of the water resource. With that aim, in 2010, the National Policy for the Integral Management of Water Resources was formulated with the objective of guaranteeing the sustainability of water resources through efficient and effective management and use. The policy articulated regulations for the territories and ecosystems containing bodies of water to ensure equitable and inclusive use of these waters, given that water is a factor of economic development and social welfare.

To this end, the National Water Plan was formulated. The Plan comprises three phases, the last of which concludes in 2022. This Plan guides the formulation of action plans that must be implemented by environmental authorities and territorial entities in the management of hydric resources' quantity, quality, and use, with special attention being paid to the risk of shortages.

The programs included in the Plan are as follows: knowledge and management of water resource information (hydric regulation and water resource modeling in the second phase); groundwater; articulation; planning and management of water resources; legalization and registration of users of water resources; control of contamination and efficient use of water resources; linking productive 
sectors to the integrated management of water resources; prevention of risks associated with hydric resources; strengthening of environmental authorities in the integral management of water resources; financial sustainability for the integral management of water resources and water culture; and participation and management of conflicts related to water resources.

The instruments required for the execution of the programs outlined in the Plan were developed by the Ministry of Environment and Sustainable Development; for example, the Plans for Ordination and Management of Watersheds set out guidelines for proper use and management of water resources, with the purpose of guaranteeing efficient use of water for productive purposes.

Thus, the relevant environmental authorities can establish the classification of a water resource; set its destination and its possibilities of use; define the quality objectives to be achieved in the short, medium, and long term; establish the rules of preservation of the quality of the resource to ensure the conservation of the biological cycles and the normal development of the species; determine the cases in which the activities, such as fishing and sports, should be banned completely, partially, temporally or indefinitely; establish the areas in which the discharge of residual water or liquid or gaseous waste from industrial or domestic urban or rural sources into surface, groundwater, or marine waters shall be prohibited or conditioned; and establish a monitoring program for water resources in order to verify the efficiency and effectiveness of resource management.

Regional autonomous corporations[17] are the environmental authorities in Colombia. These corporations approve or deny requests for the use of water resources, according to state regulations on surface and groundwater (Decree 1541 of 1978), uses of the water resource, dumping of the water resource (Decree 3930 of 2010), and registry of users (Decree 303 of 2012). They also establish and collect taxes, as well as contributions and fines for the use and exploitation of water resources.

As environmental authorities, autonomous corporations must evaluate, control and monitor the quality of water resources, water uses, and landfills;

17 The regional autonomous corporations are corporate entities of a public nature, created by law, integrated by territorial entities that exist in the same ecosystem or comprise a geopolitical, biogeographic, or hydrogeographic unit. These corporations are endowed with administrative and financial autonomy, patrimony, and legal entity. By law, they administer the environment and renewable natural resources within the areas of their respective jurisdictions and promote sustainable development in accordance with the legal provisions and policies of the Ministry of the Environment. 
impose and execute enforcement measures and penalties established in the law; formulate, implement and co-finance programs and projects for the recovery, restoration, rehabilitation, and conservation of water resources; formulate and implement water culture projects; require and follow up on the Plans for Efficient Use and Water Saving; and formulate plans for the management of watersheds according to the criteria established by the National Government.

In addition, as part of the Policy for Integral Management of Water Resources, the National Water Resources Monitoring Program was devised to respond to the need for a systematic, coherent, and appropriate monitoring to support policy implementation and monitoring, in conjunction with the other programs of the 2010-2022 National Hydric Plan.

The National Water Resources Monitoring Program includes the National Network of Hydrometeorological Stations that comprises 720 hydrological monitoring stations, which are located in the main basins of the country[18]. The stations record water levels daily to establish the natural water supply of the basin at the point of measurement (station location).

\section{HYDRIC RESOURCE MANAGEMENT IN COLOMBIA: GOVERNABILITY OR GOVERNANCE?}

To establish whether the water resource management model in the Colombian only seeks governability of the system or whether has achieved governance, its constituent elements are assessed, taking as a reference Solanes[19] account of the elements of the public politics of water governance.

In the Colombian legal system, water resources are part of the public domain of the state, which is responsible for its permanent protection to ensure a peaceful process of access and efficient use, limiting externalities and transaction costs, and the consequent losses for the general economy.

Public ownership of water resources to ensure productive utilization for social benefit has prevented the application of a private investment model in water

18 For example, Magdalena-Cauca, Sinú, San Jorge, Atrato, Meta, Amazonas, Orinoco, Sierra Nevada de Santa Marta, Catatumbo, Patía, San Juan, and Putumayo.

19 M. Solanes. Gobernanza y finanzas para la sostenibilidad del agua en América del Sur. Caracas: CAF. (2015). Recovered from https://www.caf.com/media/2630063/ gobernanza-agua-america-sur-caf.pdf 
rights; rather, what exists are administrative authorizations for its use through concessions or dumping permits, but not appropriation.

This policy was established by the Ministry of Environment and Sustainable Development and is contained in the National Policy for Integral Management of Water Resources. Its execution is the responsibility of environmental authorities, mainly the regional autonomous corporations in their respective jurisdictions.

Given that the National Water Plan is the backbone of the Integral Water Resources Management Policy, the resources required for its implementation should have been allocated accordingly. However, in 2014, the National Planning Department carried out a consultancy to estimate the financial gap for the implementation of the policy, which was calculated as the difference between the sources for water management of the Ministry of Environment and Development, Institute of Hydrology, Meteorology and Environmental Studies of Colombia, environmental authorities, and territorial entities, and the costs of policy activities for 2015-2022. The result showed an accumulated gap of 2.9 billion pesos for the environmental component of integrated water resources management, with an annual average of 374,509 million pesos (equivalent to approximately US $\$ 125 \mathrm{~m}$ ).

However, in addition to financing, an essential element to achieve the policy's implementation is the Water Resources Information System, the purpose of which is to consolidate, integrate, and standardize the gathering, registration, and consultation of data associated with water resources. The Registry of Users of the Water Resource is an important part of this system. It contains information on users, sources of use, uses (e.g. domestic, agricultural, livestock, and industrial), and concessions granted, as well any contaminations after use.

Understanding the rights and regulations pertaining to water exploitation provides environmental authorities and water users with the tools needed to identify, treat, and manage or resolve disputes when they arise. Such disputes may pertain to the use, accessibility, or affordability of the water resource. For their resolution, there is no specialized jurisdiction, and ordinary judges address these conflicts from a civilian perspective, particularly for claims regarding disturbance of possession or easements.

Water management planning instruments thus allow for the formulation of strategies and actions to improve the governability of water resources. For example, the Environmental Councils of Macrocuenca and Cuenca exhibited good coordination and participation in proposing alternative solutions to issues pertaining to the formulation or adjustment of the Plan of Ordination and 
Management of the Hydrographic Basin and the administration of the renewable natural resources of this basin.

Efficient use and water saving is the duty of entity providers of aqueduct services, sewage, irrigation, drainage, and hydroelectric production, as well as other users of the water resource, must comply with the rules of the relevant environmental authorities. The Commission for Regulation of Drinking Water and Basic Sanitation's tariff structure also promoted the efficient use of water.

\section{CONCLUSIONS AND RECOMMENDATIONS}

It can thus be concluded that the core instruments of water resource management in Colombia center on the political-institutional ambit and require the participation of social actors in the design, implementation, and monitoring of water policy. The findings of this paper indicate that the country is still seeking to consolidate the water resource management system's governability; it is therefore premature to conclude that a transition to governance has taken place in the management of water resources.

This is confirmed by the fact that there is a lack of financial resources required for the execution of the national policy. This prevents the provision of this public good in a sustainable, efficient, and equitable way. Without the necessary public funding it is not possible to achieve the governance of any system. The correlation between the need for sustainable public finances with the achievement of development objectives has already been demonstrated in the Monterrey Consensus (2002), the Doha Declaration (2008) and the Third Conference on Financing for Development (Addis Ababa, 2015).

Consequently, it is necessary to start a transition toward governance. The first step is to recognize the gaps in existing water policies and address them with innovative and democratic rules that guarantee a multi-focal basis for the implementation of new management paradigms based on local solutions for local problems related to water. This process of transformation to the "good governance" model requires extensive observation of the political, economic, social, cultural, ethnic, and environmental factors that determine water resource administration:

Achieving good water governance cannot be undertaken hastily using blueprints from outside any given county or region. Good governance needs to be developed to suit local conditions. Incremental improvement and flexibility are key. New reforms do not have to be implemented in a comprehensive or fully integrated way. However, they do have to workable and doing a few 
things well to demonstrate that new approaches work is both pragmatic and likely to generate public and political support.[20]

In addition, it is necessary that the authorities involved in the transition process in Colombia observe and apply the main principles and guidelines for an effective water governance model stated by the OECD (2015):

- Clear distinctions need to be made between roles and responsibilities for water policy making and implementation.

- Water management should take place at the appropriate scales.

- There should be effective coordination between policies for water and the environment.

- Transparency is needed in all the information related to water management.

- Good administration of financial resources is needed for water management.

- Strong and effective accountability methods that guarantee the accomplishment of the policies formulated should be implemented.

- Innovative practices and good water governance practices should be implemented.

- Methods that guarantee full participation of all the social and economic sectors involved in water management should be developed and applied.

According to Batchelor, the main characteristics of effective water governance are open and transparent, inclusive and communicative, coherent and integrative, equitable and ethical, accountable, efficient, and responsive and sustainable.

These principles and characteristics are applicable for the Colombian case, to start a progressive transition process towards an effective water governance model; nevertheless, public policies conceived under water governance models

20 C. Batchelor. Water governance literature assessment. International Institute for Environment and Development (2007). Recovered from http://pubs.iied.org/pdfs/ G02523.pdf? 
face similar challenges as those related to environmental change, poverty reduction, and the fight against corruption.

The country now faces the challenge of generating a water resource management model based on open institutions, transparency, environmental democracy, the ecologic constitution, social inclusion, sustainable development, accountability, efficiency, and institutional responsibility.

\section{REFERENCES}

BATCHELOR, CHARLES. Water governance literature assessment. International Institute for Environment and Development (2007). Recovered from http:/ / pubs.iied.org/ pdfs/G02523.pdf?

CASTRO, JOSÉ ESTEBAN. Water governance in the twentieth-first century. Ambiente \& Sociedade, 10 (2), 97-118 (2007). Recovered from https:/ / doi.org/10.1590/S1414$753 \times 2007000200007$

Defensoría del Pueblo. Avance del derecho humano al agua en la Constitución, la ley, la Jurisprudencia y los instrumentos internacionales 2005-2011. Bogotá, D.C. (2012).

Global Water Partnership. Principios de gestión integrada de los recursos hídricos. Bases para el desarrollo de los planes nacionales (2008). Recovered from https:/ / agua.org.mx / wp-content/uploads/2011/10/principios_gestion_integrada_recursos_ hidricos.pdf

IZA, ALEJANDRO, \& ROVERE, MARTA B. (Eds.) Gobernanza del agua en América del Sur: Dimensión ambiental. Cambridge: UICN (2006). Recovered from https:// www.iucn.org/sites/dev/files/import/downloads/gobernanza.pdf

Ministerio de Ambiente, Vivienda y Desarrollo. Política nacional para la gestión integral del recurso hídrico. Bogotá (2010). Recovered from http:/ / extwprlegs1.fao.org/docs/ pdf/col146504.pdf

OECD. OECD Principles on Water Governance. Paris. Recovered from http:// www.oecd.org/cfe/regional-policy/OECD-Principles-on-Water-Governance.pdf

PEÑA, HUMBERTO \& SOLANES, MIGUEL. La gobernabilidad del agua en las Américas, una tarea inconclusa (2002). Recovered from https://gestionsostenibledelagua. files.wordpress.com/2010/09/gobernabilidad-del-agua-en-las-americas-una-tarea-inconclusa.pdf

ROGERS, PETER \& HALL, ALAN W. Effective Water Governance (Vol. 7). Stockholm: Global Water Partnership (2003). Recovered from https://www.gwp.org/ 
globalassets/global/toolbox/ publications/background-papers/07-effectivewater-governance-2003-english.pdf

SALCIDO, SILVIA, GERRITSEN, PETER R., \& MARTÍNEZ, LUIS MANUEL. Gobernanza del agua a nivel local: estudio de caso en el municipio de Zapotitlán de Vadillo, Jalisco. El Cotidiano (162), 83-89 (2008). Recovered from http:// www.redalyc.org/pdf/325/32513882010.pdf

SOARES, DENISE, VARGAS, SERGIO, \& NUÑO, MARÍA ROSA. La gestión de los recursos hídricos: realidades y perspectivas. Guadalajara: Instituto Mexicano de Tecnología del Agua, Universidad de Guadalajara (2008). Recovered from https:/ /sendas99.files.wordpress.com/2009/01/capitulo_gestion_cuenca-pixquiac.pdf

SOLANES, MIGUEL. Gobernanza y finanzas para la sostenibilidad del agua en América del Sur. Caracas: CAF (2015). Recovered from https:/ / www.caf.com/media/2630063/ gobernanza-agua-america-sur-caf.pdf

UN System Task Team on the Post-2015 UN Development Agenda. Governance and development Thematic Think Piece UNDESA, UNDP, UNESCO (2015). Recovered from http://www.un.org/millenniumgoals/pdf/Think\%20Pieces/7_governance.pdf 